\title{
Pelatihan Pembuatan Gula Semut Aren dan Jahe Instan di Desa Botosari, Paninggaran, Pekalongan
}

\section{(Training on Making Palm Sugar and Instant Ginger Beverage in Botosari Village, Paninggaran, Pekalongan)}

\author{
Achmad Mujib' ${ }^{*}$, Aji Hermawan',3, Sugeng Hari Suseno ${ }^{2,4}$, Danang Aria Nugroho', \\ Prayoga Suryadarma ${ }^{2,5}$ \\ ${ }^{1}$ Fasilitator Stasiun Lapang Agro Kreatif Lembaga Penelitian dan Pengbdian kepada Masyarakat, Institut Pertanian Bogor, \\ Kampus IPB Darmaga, Bogor 16680. \\ 2 Lembaga Penelitian dan Pengbdian kepada Masyarakat, Institut Pertanian Bogor, Kampus IPB Darmaga, Bogor 16680. \\ ${ }^{3}$ Sekolah Bisnis, Institut Pertanian Bogor, Kampus IPB Gunung Gede, Jl. Raya Pajajaran, RT.03/RW.06, \\ Babakan, Bogor Tengah, Bogor 16128. \\ ${ }^{4}$ Departemen Teknologi Hasil Perairan, Fakultas Perikanan dan Ilmu Kelautan, Institut Pertanian Bogor, \\ Kampus IPB Darmaga, Bogor 16680. \\ 5 Departemen Teknologi Industri Pertanian, Fakultas Teknologi Pertanian, Institut Pertanian Bogor, \\ Kampus IPB Darmaga, Bogor 16680. \\ *Penulis Korespondensi: achmadm11s16@apps.ipb.ac.id \\ Diterima Mei 2019/Disetujui September 2019
}

\begin{abstract}
ABSTRAK
Gula aren merupakan salah satu jenis pemanis yang banyak ditemui di Indonesia. Masyarakat Gunung Surat, Desa Botosari, Paninggaran, Kabupaten Pekalongan telah lama memproduksi gula aren cetak secara tradisional, namun dengan kualitas yang masih rendah dan dijual secara curah. Hal ini menyebabkan nilai jual gula aren menjadi rendah. Kegiatan pelatihan pembuatan gula semut dan jahe instan ini bertujuan untuk memberikan pengetahuan kepada masyarakat tentang diversifikasi produk gula aren yang bernilai jual tinggi. Pelaksanaan pelatihan ini adalah dengan penyampaian materi dan praktik pembuatan produk. Hasil dari pelatihan ini adalah masyarakat Gunung Surat, Desa Botosari khususnya anggota Industri Kecil Menengah (IKM) gula aren mengetahui proses pembuatan gula semut dan jahe instan. Melalui pembuatan diversifikasi produk gula aren tersebut diharapkan mampu meningkatkan pendapatan dan kesejahteraan masyarakat setempat.
\end{abstract}

Kata kunci: aren, diversifikasi, gula semut, Gunung Surat, jahe instan

\begin{abstract}
Palm sugar is one of the sweateners which is commonly found in Indonesia. People of Gunung Surat, Botosari Village, Paninggaran, Pekalongan Regency have traditionally produced palm sugar, but the palm sugar is still low quality and sold in bulk. This condition makes the selling value of palm sugar to be low. The aim of the training on making palm sugar and instan ginger beverage was to provide knowledge for the public about the diversification of palm sugar products with high selling value. The implementation of this training was to deliver material and practice of making products. The results of this training was the people of Gunung Surat, Botosari Village, especially members of the palm sugar IKM, know the process of making palm sugar and instant ginger beverage. Through making diversification of palm sugar products, it is expected to be able to increase the income and welfare of the local community.
\end{abstract}

Keywords: diversification, Gunung Surat, instan ginger beverage, palm sugar, sugar palm

\section{PENDAHULUAN}

Aren (Arenga pinata) merupakan salah satu tanaman dari keluarga Arecaceae yang hampir tersebar di seluruh daerah di Indonesia, termasuk di Pulau Jawa. Tanaman aren dapat tumbuh dari dataran rendah hingga ketinggian $1400 \mathrm{mdpl}$ (Mariati 2013). Pohon aren memiliki nilai ekonomi tinggi karena hampir semua bagiannya dapat dimanfaatkan (Lempang 2012). Serabut batangnya dimanfaatkan untuk bahan baku pembuatan sapu, buahnya atau yang banyak dikenal dengan sebutan kolang-kaling sering dikonsumsi menjadi berbagai olahan makanan, akarnya dapat diolah menjadi jamu, dari batangnya dihasilkan pati dan tepung sagu, dan niranya digunakan untuk memproduksi gula aren. Pemanfaatan pohon aren telah lama dan 
banyak dilakukan oleh masyarakat, salah satu yang banyak adalah pembuatan gula aren.

Gunung Surat adalah salah satu dusun di Desa Botosari, Kecamatan Paninggaran, Kabupaten Pekalongan. Gunung Surat berjarak $30 \mathrm{~km}$ dari ibu kota Kabupaten Pekalongan dan berbatasan langsung dengan Kecamatan Kalibening, Kabupaten Banjarnegara. Secara geografis Dusun Gunung Surat merupakan daerah perbukitan dengan ketinggian 1350 mdpl. Berbagai tanaman perkebunan banyak tumbuh di daerah ini seperti teh, kopi, kakao, cengkeh, dan aren. Terdapat lebih dari 500 pohon aren di Dusun Gunung Surat yang sebagiannya telah dimanfaatkan oleh penduduk setempat sebagai bahan baku produksi gula aren atau gula jawa. Terdapat kurang lebih 20 keluarga yang saat ini manjadi pengrajin gula aren di Gunung Surat.

Gula aren yang dihasilkan oleh masyarakat Gunung Surat saat ini masih berupa gula cetak. Teknologi produksi gula aren cetak juga masih tradisional, dengan peralatan yang sederhana dan manual. Hasil gula aren dijual secara curah melalui kelompok usaha bersama sebelum nantinya di jual ke pasar. Selain itu secara alami gula cetak mengandung kadar air yang lebih tinggi, yaitu sebesar $10 \%$ dibandingkan gula semut yang hanya sebesar 3\% (SNI 1995). Bahkan umumnya hasil olahan gula cetak di tingkat petani dan industri rumah tangga mutunya masih rendah disebabkan pengolahan belum dilakukan secara baik, sehingga produk yang dihasilkan cepat meleleh, karena masih mengandung kadar air cukup tinggi sebesar 15-17\% (Kindangen \& Layuk 2011). Hal ini menyebabkan umur simpan gula cetak lebih pendek. Faktor-faktor tersebut akhirnya membuat harga gula aren cetak menjadi murah, sehingga pendapatan keluarga dari hasil produksi gula aren belum bisa dikatakan sejahtera. Ada satu nilai yang sangat potensial untuk diangkat dan dapat menaikkan harga jual gula aren Gunung Surat, yaitu produknya yang organik.

Tanaman lain yang potensial untuk dikembangkan produk turunannya di daerah Gunung Surat adalah jahe merah (Zingiber officinale Linn. var. Rubrum). Tanaman rimpang dari keluarga Zingiberceae sering dikonsumsi sebagai obat tradisional atau jamu (Arini \& Hadisoewignyo 2012). Jahe merah mengandung senyawa volatile yang terdiri dari berbagai senyawa terpenoid, senyawa non-volatile terdiri dari gingerol, shogaol, paradol, zingerone, dan turunan mereka serta senyawa-senyawa flavonoid dan polifenol yang mempunyai efek antioksidan dapat mencegah adanya radikal bebas dalam tubuh (Stailova et al. 2007). Jahe merah tumbuh liar dan masih sedikit pemanfaatannya di Dusun Gunung Surat. Berbagai produk olahan yang bernilai ekonomis tinggi dapat dihasilkan dari jehe merah ini (Bartley \& Jacobs 2000), salah satunya adalah minuman jahe instan.

Lembaga Penelitian dan Pengabdian Masyarakat Institut Pertanian Bogor (LPPM IPB) bekerja sama dengan Pemerintah Kabupaten Pekalongan melalui Program Stasiun Lapang Agro Kreatif (SLAK) melakukan pelatihan produksi gula semut dan jahe instan di Dusun Gunung Surat, Desa Botosari, Kecamatan Paninggaran, Pekalongan. Pelatihan ini bertujuan untuk memberikan pengetahuan kepada masyarakat Gunung Surat khususnya dan Desa Botosari pada umumnya tentang diversifikasi produk gula aren, di antaranya adalah gula semut dan jahe instan. Setelah mengikuti pelatihan masyarakat diharapkan mampu membuat gula semut dan jahe instan. Kedepannya penghasilan masyarakat setempat juga dapat naik, karena harga jual gula semut dan jahe instan lebih tinggi dibandingkan gula aren cetak.

\section{METODE PELAKSANAAN KEGIATAN}

\section{Tempat, Waktu, dan Peserta}

Kegiatan pengabdian masyarakat dilaksanakan pada Bulan Maret 2019 di Dusun Gunung Surat Desa Botosari, Kecamatan Paninggaran, Kabupaten Pekalongan. Mitra dari kegiatan ini adalah warga Dusun Gunung Surat, Desa Botosari, yang terdiri dari para penyadap aren, pembuat gula aren, dan pengurus kelompok usaha bersama yang berjumlah 20 orang. Para penyadap semuanya adalah laki-laki dan pembuat gula aren mayoritas ibu rumah tangga. Usia peserta variatif antara rentang 19-60 tahun.

\section{Alat dan Bahan}

Alat yang digunakan dalam pelatihan ini adalah kompor, alat penggorengan, pisau, alat pemarut, ayakan, gelas stainless, baskom, dan toples kaca. Bahan yang digunakan adalah gula aren cetak, air, jahe merah, minyak goreng, dan gula pasir.

\section{Tahapan dan Metode Pelaksanaan}

Kegiatan pelatihan dibagi menjadi dua sesi, yaitu penyampaian materi di dalam ruangan oleh narasumber dan praktik pembuatan produk. 


\section{- Penyampaian materi}

Penyampaian meteri ini bertujuan untuk membuka wawasan peserta pelatihan tentang diversifikasi produk dari gula aren dan potensinya untuk meningkatkan kesejahteraan masyarakat. Selain penyampaian materi, kegiatan ini dilakukan dengan metode diskusi langsung dengan para peserta pelatihan.

\section{- Praktik pembuatan produk}

Praktik pembuatan produk dilakukan di luar ruangan balai desa. Produk yang akan dibuat adalah gula semut dan jahe instan. Pembuatan gula semut saat praktik menggunakan bahan baku gula aren cetak atau gula merah, bukan menggunakan nira. Hal ini bertujuan agar proses pemasakan tidak terlalu lama.

Praktik pembuatan produk dimulai dengan pembagian kelompok menjadi dua. Satu kelompok membuat gula semut dan yang satunya jahe instan. Pembuatan gula semut dimulai dengan penyiapan bahan, yaitu mengecilkan ukuran gula cetak dengan mengirisnya. Proses selanjutnya melarutkan gula cetak dan kemudian memasaknya hingga mengental. Larutan gula yang sudah mengental kemudian diaduk terus menerus hingga kering dan terbentuk kristal. Proses terakhir adalah mengayak gula semut tersebut agar didapatkan ukuran yang seragam.

Kelompok jahe instan memulai praktiknya dengan memarut jahe merah dan memerasnya dengan air (perbandingan $1 \mathrm{~L}$ air : $250 \mathrm{~g}$ jahe). Air perasan jahe diendapkan terlebih dahulu hingga pati jahe mengendap. Air perasan jahe ini kemudian digunakan untuk melarutkan gula aren yang sudah diiris tipis (perbandingan $1: 1$ ), selanjutnya dimasak seperti pada proses pembuatan gula semut.

\section{HASIL DAN PEMBAHASAN}

Sehari sebelum dilaksanakannya pelatihan, tim fasilitator LPPM IPB bersama perwakilan Dinas Perindustrian, Perdagangan, Koperasi, dan UKM Kabupaten Pekalongan melakukan koordinasi dengan pemerintah desa setempat dan kelompok usaha bersama. Koordinasi ini bertujuan untuk mematangkan persiapan pelatihan. Beberapa kebutuhan terkait pelatihan dipastikan kesiapannya. Turut hadir dalam koordinasi Kepala Dusun Gunung Surat, Ketua Kelompok Usaha Bersama, beserta para Industri Kecil Menengah (IKM). Pelatihan dilaksanakan pada tanggal 1 Maret 2019, dibuka secara langsung oleh perwakilan Dinas Perindustrian, Perdagangan, dan Koperasi Kabupaten Pekalongan.

\section{Penyampaian Materi}

Pelatihan pembuatan diversifikasi produk gula aren, dalam program ini adalah gula semut dan jahe instan, dimulai dengan penyampaian materi di dalam ruangan. Materi disampaikan oleh narasumber yang merupakan perwakilan dari LPPM IPB. Kegiatan berlangsung di balai Desa Botosari yang diikuti oleh 20 orang peserta. Peserta yang mengikuti pelatihan berasal dari Desa Botosari utamanya dari Dusun Gunung Surat yang berprofesi sebagai pengrajin gula aren. Penyampaian materi kurang lebih satu jam dan sesi diskusi 15 menit.

Materi yang disampaikan dalam pelatihan kali ini difokuskan pada proses pembuatan gula semut dan jahe instan. Beberapa faktor kritis yang menyebabkan berhasilnya proses pembuatan gula semut sangat ditekankan, seperti kualitas bahan baku, yaitu nira aren, dan proses pemasakan. Perlakuan nira aren harus diperhatikan agar tidak terjadi fermentasi sebelum dimasak. Nira yang telah terfermentasi tidak akan dapat mengkristal jika diolah menjadi gula semut, ini dikarenakan telah terbentuk enzim invertase yang akan mengubah kandungan sukrosa menjadi gula reduksi (Goutara \& Wijandi 1980; Tomomatsu et al. 1996). Kandungan sukrosa lah yang menentukan terbentuknya kristal pada proses gula semut (Ho et al. 2007).

Materi pelatihan disampaikan dengan bahasa yang komunikatif sehingga peserta sangat tertarik (Gambar 1). Hal ini ditunjukkan dengan beberapa peserta yang mengajukan pertanyaan. Pertanyaan tidak hanya terkait gula semut namun juga kualitas gula cetak yang diproduksi sehari-hari oleh para pengrajin. Peserta menanyakan kualitas gula yang tidak seragam antar pengrajin, dimana hal ini juga akan me-

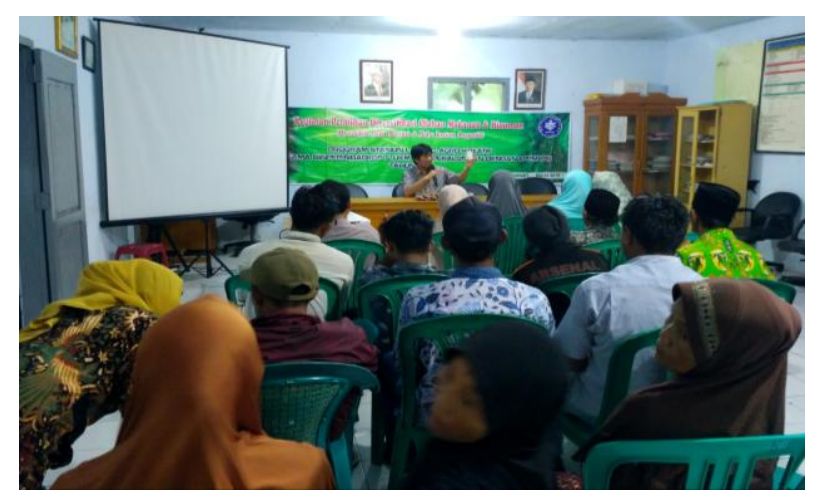

Gambar 1 Penyampaian materi pelatihan. 
mengaruhi harga jual gula. Berdasarkan pemaparan pemateri kualitas yang tidak seragam tersebut diduga diakibatkan karena kualitas nira yang tidak sama antar-pohon, selain proses yang dilakukan antar-pengrajin juga yang belum distandardisasi. Selai itu di antara peserta ada juga yang menanyakan teknik penyadapan. Beberapa tangkai bunga aren kadang sulit mengeluarkan nira lagi ketika telah disadap beberapa kali meskipun tangkai tersebut masih panjang. Untuk menangani hal ini pemateri menyarankan penyayatan tangkai bunga agar diperdalam, karena dikhawatirkan permukaan tangkai yang mengeras sudah agak dalam.

\section{Praktik Pembuatan Gula Semut dan Jahe Instan}

Praktik pembuatan gula semut dan jahe instan dilaksanakan setelah penyampaian materi di dalam kelas. Peserta pelatihan kemudian dibagi menjadi dua kelompok, satu kelompok berjumlah 10 orang untuk membuat gula semut, dan satu kelompok yang lain berjumlah 10 orang untuk membuat jahe instan. Pembagian peserta dilakukan secara acak dan merata, sehingga satu kelompok terwakili oleh penyadap aren dan pembuat gula cetak serta pengurus KUB. Praktik dimulai dengan penyiapan bahan dan alat, seperti mamasang regulator pada tabung gas, memebersihkan alat masak, memotong gula aren cetak menjadi ukuran kecil, dan memarut jahe.

Pembuatan gula semut aren dapat dilakukan dengan tiga cara, yang pertama dengan memasak nira aren hingga mengkristal. Hal tersebut merupakan cara pembuatan gula semut yang sebenarnya. Gula semut yang dihasilkan dari proses ini akan memiliki warna yang cerah dan menarik. Proses pembuatan gula semut yang lain adalah dengan melarutkan gula merah cetak dan memasaknya kembali hingga mengkristal. Proses ini memiliki kerentanan pada proses kristalisasinya. Gula cetak yang kualitasnya tidak baik akan menyebabkan gula tidak dapat mengkristal, sehingga gula semut tidak dapat terbentuk. Selain itu warna gula semut yang dihasilkan akan berwarna gelap, karena melewati dua kali pemanasan. Proses pembuatan gula semut yang lain adalah dengan mengecilkan ukuran gula cetak (hingga kurang lebih 18 mesh) kemudian dikeringkan menggunakan oven.

Proses pembuatan gula semut pada pelatihan ini menggunakan metode pelarutan gula aren cetak (Gambar 2). Hal ini dilakukan untuk mengantisipasi lamanya waktu pemasakan. Setelah pelatihan yang diadakan di balai Desa

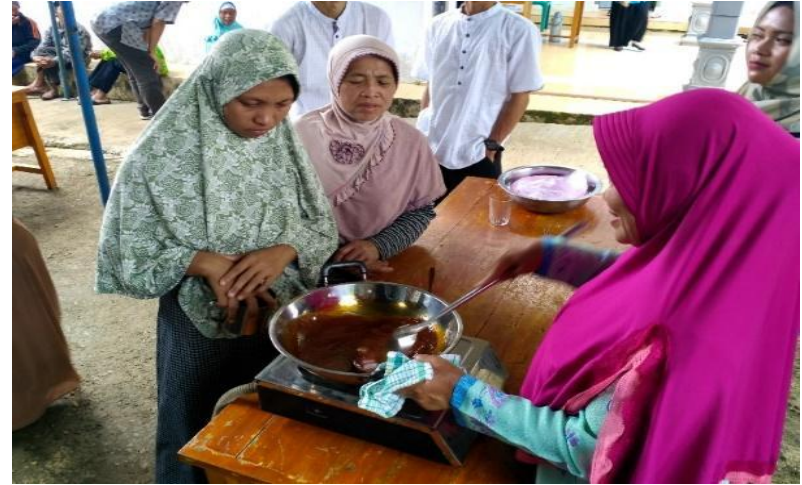

Gambar 2 Pemasakan gula semut.

Botosari ini akan dilakukan pendampingan oleh fasilitator dari LPPM IPB selama kurang lebih empat bulan. Pada saat pendampingan IKM dibantu oleh fasilitator diharapkan mampu memproduksi gula semut menggunakan bahan baku nira aren.

Dalam praktik pembuatan gula semut dan jahe instan yang dilaksanakan di balai Desa Botosari ini para peserta mengalami kendala. Hasil dari keduanya tidak berhasil membentuk kristal. Hal ini diduga karena kualitas gula cetak yang digunakan kurang baik. Gula cetak yang baik memiliki tekstur yang keras dan berwarna cokelat cerah, sedangkan gula cetak yang digunakan saat pelatihan memiliki tekstur kurang keras dan mudah dipatahkan. Hal ini disebabkan karena produksi gula cetak yang dilakukan IKM setempat manggunakan nira yang disirupkan dan sudah tersimpan lebih dari satu hari. Kebiasaan ini dilakukan warga untuk mengatasi ketersediaan nira pada saat hasil sadapan tidak banyak.

Pemateri beserta peserta mencoba membuat jahe instan menggunakan gula pasir (gula tebu) untuk membuat perbandingan dan membuktikan proses pembuatan gula semut dan jahe instan sudah benar. Komposisi dan proses yang digunakan sama dengan pembuatan jahe instan menggunakan gula aren cetak. Setelah satu jam proses pemasakan, jahe instan yang diproses menggunakan bahan baku gula pasir berhasil mengkristal. Hal ini dapat membuktikan bahwa kualitas gula cetak yang kurang baik mengakibatkan tidak terbentuknya kristal pada gula semut maupun jahe instan gula aren.

Setelah dilakukan penyampaian materi dan melakukan praktik langsung, seluruh peserta mengetahui tahapan proses pembuatan gula semut dan jahe instan yang awalnya sama sekali tidak pernah membuatnya. Hal ini menjadi modal awal bagi para peserta pelatihan untuk mencobanya sendiri di rumah seusainya pelatihan ini. 
Proses pembuatan yang tidak jauh beda dengan pembuatan gula cetak biasa turut mempercepat terserapnya materi.

\section{Keberlanjutan Kegiatan}

Program SLAK kerja sama antara Lembaga Penelitian dan Pengabdian Masyarakat IPB dengan pemerintah Kabupaten Pekalongan adalah serangkaian kegiatan pelatihan dan pendampingan selama kurang lebih empat bulan. Kegiatan pelatihan di balai Desa Botosari merupakan awal dari kegiatan-kegiatan empat bulan berikutnya. Selama pendampingan anggota IKM akan memperoleh pelatihan tentang produksi gula semut secara menyeluruh dari Good Manufacturing Practices (GMP) hingga pengemasan dan pemasaran produk. Selain gula semut, produk turunannya seperti jahe instan gula aren dan cokelat instan gula aren juga akan diproduksi.

Diversifikasi produk gula aren tersebut diharapkan mampu menaikkan pendapatan anggota IKM dan petani aren di Desa Botosari khusunya Dusun Gunung Surat. Melihat potensi pasar gula semut yang besar harapan tersebut tentunya sangat mungkin diwujudkan. Produk gula semut dalam negeri juga mampu bersaing di pasar internasional. Hal ini dibuktikan dari permintaan ekspor gula semut yang terus meningkat. Sejak tahun 2014-2017 terdapat kenaikan permintaan ekspor sebesar $27 \%$ senilai USD 48.000 (Kemenperin 2018). Negara utama tujuan ekspor gula semut antara lain Jerman, Swiss, dan Jepang (BI 2009).

\section{SIMPULAN}

Kegiatan pengabdian masyarakat melalui program SLAK telah membuka wawasan baru kepada masyarakat Desa Botosari, khususnya Dusun Gunung Surat. Melalui pelatihan pembuatan diversifikasi produk gula aren, selain memberi pengetahuan baru juga menumbuhkan semangat masyarakat setempat utamanya anggota IKM gula aren untuk meningkatkan kondisi ekonomi mereka. Peningkatan nilai tambah produk gula aren melalui pembuatan gula semut dan jahe instan kedepannya diharapkan mampu menaikkan pendapatan dan kesejahteraan masyarakat setempat. Setelah mengikuti pelatihan ini para peserta, secara teknis, mengetahui proses pembuatan gula semut dan jahe instan, namun pendampingan masih dibutuhkan untuk mengawal IKM hingga pada skala produksi. Pendampingan ini akan dilakukan kurang lebih empat bulan setelah pelatihan ini.

\section{UCAPAN TERIMA KASIH}

Ucapan terima kasih disampaikan kepada Lembaga Penelitian dan Pengabdian Masyarakat IPB, Pemerintah Kabupaten Pekalongan, khususnya dalam hal ini Dinas Perindustrian, Perdagangan dan Koperasi Kabupaten Pekalongan, dan Pemerintah Desa Botosari, khususnya Kepala Dusun Gunung Surat yang telah memfasilitasi dan mendukung kegiatan pengabdian ini.

\section{DAFTAR PUSTAKA}

Arini HD, Hadisoewignyo L. 2012. Optimasi Formula Tablet Effervescent Ekstrak Rimpang Jahe Merah (Zingiber officinale roxb. Var rubrum). Jurnal Farmasi Sains dan Komunitas. 9(2): 75-84.

Bartley JP, Jacobs AL. 2000. Effects Of Drying On Flavor Compounds In Australian-Grown Ginger (Zingiber officinale). Journal of the Science of Food and Agriculture. 80(2): 209215 . https://doi.org/10.1002/(SICI)10970010(20000115)80:2<209:AID-JSFA516> 3.0.CO;2-8

[BI] Bank Indonesia. 2009. Pola Pembiayaan Usaha kecil Syariah Gula Aren (Gula Cetak dan Gula Semut. Jakarta (ID): Direktorat Kredit, BPR danUMKM

Goutara, Wijandi S. 1980. Dasar-dasar Pengolahan Gula. Bogor: IPB Press.

Ho CW, Aida WW, Maskat MY, Osman H. 2007. Changes in volatile compounds of palm sap (Arenga pinnata) during the heating process for production of palm sugar. Food Chemistry. 102(4): 1156-1162. https://doi.org/ 10.1016/j.foodchem.2006.07.004

[Kemenperin]. 2018. Pasar Ekspor Gula Semut. [Internet]. [dikunjungi pada 15 Maret 2019]. Tersedia Pada: http://www.kemenperin. go.id/artikel/19197/Naik-27-Persen,Ekspor-Gula-Semut-Nasional-Lampaui-USD48-Ribu.

Kindangen JG, Layuk P. 2010. Analisis pendapatan dan sistem pemasaran 
pengusahaan gula merah aren di Desa Wongkaidan Pangu, Kecamatan Ratahan, Kabupaten Minahasa Tenggara, Provinsi Sulawesi Utara. Seminar Nasional Pengkajian dan Diseminasi Inovasi Pertanian Mendukung Program Strategis Kementerian Pertanian. Cisarua, 9-11 Desember 2010.

Lempang M. 2012. Pohon Aren Dan Manfaat Produksinya. Info Teknis Eboni. 9(1): 37-54.

Mariati R. 2013. Potensi Produksi dan Prospek Pengembangan Tanaman Aren (Arenga pinnataMerr) di Kalimantan Timur. Agrifor. 12(2): 196-205.
[SNI] Standar Nasional Indonesia. 1995. Standar Nasional Indonesia Nomor SNI 01-3743-1995 Tahun 1995.

Stailova I, Krastanov A, Stoyanova A, Denev P, Gargova S. 2007. Antioxsidant Activity of Ginger Extract (Zingiber officinale). Food Chemistry. 102(3): 764-70. https://doi.org/ 10.1016/j.foodchem.2006.06.023

Tomomatsu A, Itoh T, Wijaya $\mathrm{CH}$, Nasution Z, Kumendong J, Matsuyama A. 1996. Chemical constituents of sugar-containing sap and brown sugar from palm in Indonesia. Japanese Journal of Tropical Agriculture. 40(4): 175181. 